\title{
FACTORS ASSOCIATED WITH WORK PERFORMANCE AMONG MIDWIVES AT COMMUNITY HEALTH CENTERS IN CENTRAL JAVA
}

\author{
Nurul Wahidah'), Endang Sutisna Sulaeman²), \\ Uki Retno Budihastuti3)
}

\author{
1)Masters Program in Public Health, Universitas Sebelas Maret \\ 2) Department of Public Health, Universitas Sebelas Maret \\ 3)Department of Obstetrics and Gynecologi, Dr. Moewardi Hospital, Surakarta
}

\begin{abstract}
Background: Performance of midwives in antepartum, intrapartum, and postpartum health care can influence maternal health as well as infant survival. Despite its importance, studies into factors associated with work performance among widwives in Indonesia are scanty. This study aimed to investigate factors associated with work performance among midwives at Community Health Centers in Central Java.

Subjects and Method: This was a cross-sectional study carried out at 28 Puskemas (Community Health Centers) in Sukarta and Karanganyar, Central Java, Indonesia. A sample of 28 Puskesmas was selected for this study by stratified random sampling, comprising of 5 strata of Puskesmas. A total sample of 200 midwives was selected for this study by random sampling. Around 4 to 14 midwives were selected randomly from each selected Puskesmas, resulting in a total sample of 200 midwives. The dependent variable was work performance. The independent variables included knowledge, experience, tenure, motivation, job burden, facility, skill, and reward. The data were collected by pre-tested questionnaire and analyzed by a multiple logistic regression.

Results: Work performance was positively associated with knowledge (OR=6.96 $95 \% \mathrm{CI}=2.88$ to $16.82 ; \mathrm{p}<0.001)$, experience $(\mathrm{OR}=2.39 ; 95 \% \mathrm{CI}=1.12$ to $5.13 ; \mathrm{p}=$ $0.025)$, tenure $(\mathrm{OR}=2.69 ; 95 \% \mathrm{CI}=1.20$ to $6.04 ; \mathrm{p}=0.016)$, motivation $(\mathrm{OR}=2.76$; $95 \% \mathrm{CI}=1.22$ to $5.59 ; \mathrm{p}=0.014)$, facility $(\mathrm{OR}=2.91 ; 95 \% \mathrm{CI}=1.32$ to $6.41 ; \mathrm{p}=$ o.0o8), skill $(\mathrm{OR}=2.59 ; 95 \% \mathrm{CI}=1.11$ to $6.11 ; \mathrm{p}=0.030)$, and reward $(\mathrm{OR}=2.08$; $95 \% \mathrm{CI}=0.97$ to $4.46 ; \mathrm{p}=0.061$ ), but was negatively associated with job burden $(\mathrm{OR}=0.36 ; 95 \% \mathrm{CI}=0.16$ to $0.82 ; \mathrm{p}=0.015)$.

Conclusion: Work performance is positively associated with knowledge, experience, tenure, motivation, facility, skill, and reward, but is negatively associated with job burden, among midwives working at Puskesmas.
\end{abstract}

Keywords: work performance, knowledge, experience, tenure, motivation, facility, skill, reward, job burden, midwife.

\section{Correspondence:}

Nurul Wahidah. Masters Program in Public Health, Universitas Sebelas Maret. Jl. Ir. Sutami No. 36 A, 57126, Surakarta, Central Java.

Email: wahidahnurul246@gmail.com. Mobile: 085764839945. 